\title{
A 2D geomechanical model of an offshore gas field in the Bredasdorp Basin, South Africa
}

\author{
Kalidhasen Ramiah ${ }^{1} \cdot$ Kaushalendra B. Trivedi $^{2} \cdot$ Mimonitu Opuwari $^{1}$
}

Received: 29 November 2017 / Accepted: 27 July 2018 / Published online: 2 August 2018

(c) The Author(s) 2018

\begin{abstract}
This case study involves the unique application of density correction software applied to density data, prior to the estimation of geopressure gradients. The K-R gas field was discovered in 1983 about $50 \mathrm{~km}$ west, off the F-A gas field offshore South Africa. During exploration; gas discoveries were made in well KR-1 and KR-8, potentially commercial gas and encouraging oil flow rates in well KR-2, KR-4 and KR-6, a dry well for KR-5 and a dry well with encouraging oil shows in KR-3. The aim of this study is to create a model that evaluates the geomechanical behaviour of the upper shallow marine reservoir (USM) of the Bredasdorp Basin, South Africa and provide a safe drilling mud window for future work in the area. The K-R field has a strong NW-SE fault trend, resulting in a maximum horizontal stress orientation of $125^{\circ}$, determined from structural depth maps. All geopressure gradients were modelled using the drillworks ${ }^{@}$ software at the top (TUSM) and bottom (BUSM) of the reservoir. The Eaton method, that can predict pore pressure from either velocity or resistivity, was used to calculate both pore pressure and fracture gradient and then calibrated using "real" data from well completion and driller's reports. The pore pressure and fracture gradient are what set the upper and lower mud weight limits. These values range between 8.46 and $9.60 \mathrm{ppg}$ and 10.12-15.33 ppg, respectively. The rock mechanical properties (Friction angle, cohesive strength and uniaxial compressive strength) were empirically derived and show a similar trend for all wells. The drilling mud window becomes more constricted at depths below $2600 \mathrm{~m}$, to the TD of the well.
\end{abstract}

Keywords Bredasdorp Basin · Geo-pressure or Geopressure · Pore pressure · Overburden · Fracture gradient $\cdot$ KR-field · Mud windows · Tectonic

\section{Introduction}

Geomechanics is a tool that has proven to be effective throughout the whole life circle of a well. Identifying and understanding the parameters controlling the geomechanics of a rock mechanics and engineering (e.g., displacement back analysis method) are essential for solving rock mechanics and engineering problems (e.g., Kirsten 1976; Jurina and Gioda 1981; Sakurai and Takeuchi 1986; Zhao 2009). Geomechanical work offshore in South Africa is in its infancy stage. This study is poised towards calculating the

Mimonitu Opuwari

mopuwari@uwc.ac.za

1 Earth Science Department, University of the Western Cape South Africa, Robert Sobukwe Road, Bellville, 7535 Cape Town, South Africa

2 Petroleum Oil and Gas Company (PetroSA) of South Africa, 151 Parow, Cape Town, South Africa magnitude and providing the direction of principal stresses, calculating rock strength parameters and calculating pore pressure and fracture gradient to evaluate the safe drilling mud window(s). The model will assess the principal stresses at reservoir depth, wellbore stability and the mud window for safe drilling.

Reservoir geomechanics is an integrated study which combines geology, petrophysics, geophysics, geochemistry, engineering, fracture and fault mechanics, and rock mechanics. A geomechanical model is a mathematical representation of the state of stress and rock mechanical properties for a field. These models are largely constructed from in situ stress magnitudes and stress directions, pore pressure, static elastic parameters and rock strength properties (Plumbet al. 2000). Geomechanics can be used throughout the technical life cycle of a field. Areas in which this tool is utilized in the petroleum industry include wellbore stability issues, sand production, pore pressure prediction, bit selection and casing design, mud weight window prediction, subsidence,

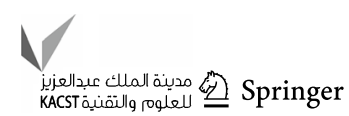


compaction and fully coupled simulation (Chardacet al. 2005).

The K-R field has had three producing wells, KR-1, KR-2, KR-3 which flowed and all the wells have faced poor wellbore conditions with regard to washouts (borehole instabilities), which led to a loss of time that had a direct impact on costs. This study amongst others is aimed at providing a post-mortem geomechanical study of the drilled K-R field wells, and thus, provides a safe operational mud window for any future wells in the field and gives a better perspective of the challenges in the field and also provides solution to avoid such problems in the future.

The K-R field is compartmentalised by faults and geomechanics is used primarily to understand how stress magnitudes, stress orientations and rock properties contribute to wellbore stability, thus outlining a safe mud window. The K-R gas field was discovered in 1983 about $50 \mathrm{~km}$ west, off the F-A gas field. During exploration; gas discoveries were made in well KR-1 and KR-8, potentially commercial gas and encouraging oil flow rates in well KR-2, KR-4 and KR-6, a dry well for KR-5 and a dry well with encouraging oil shows in KR-3. Broad, (2004) asserts that the Bredasdorp Basin is the most explored basin with proven reserves in South Africa. The extent of the basin is approximately $18,000 \mathrm{~km}^{2}$ with a water depth of less than $200 \mathrm{~m}$. Seven wells of the K-R field were selected for the geomechanical model and they can be seen in Fig. 1. The type of faults present at K-R can be classified by order of magnitude of in situ stresses. The Andersonian fault model proposed in 1951 still holds valid for today; it shows that the order of the three far-field stress magnitudes, $\sigma_{\mathrm{v}}, \sigma_{\mathrm{h}}$ and $\sigma_{\mathrm{H}}$ will indicate which faulting will occur in the reservoir (Anderson 1951).

The K-R Field has had 3 producing wells, KR-1, KR-2, KR-3 which flowed and all the wells have faced poor wellbore conditions with regard to washouts (borehole instabilities), which led to a loss of time that had a direct impact on costs. This objectives of this paper is to determine rock strength and elastic parameters from logs, understand if fault is the cause of how stress regime; indicate safe operational drilling provide wellbore stability analysis and recommend safe drilling mud weights for the area.

\section{Geological background}

The Northern Outeniqua Basin is composed of a number of echelon sub-basins; the Bredasdorp, Pletmos, Gamtoos and Algoa Basins which, together with the smaller Infanta Embayment, converge to the south to form the deeper Southern Outeniqua Basin (Broad et al. 1996). The sub-basins are grabens separated by basement arches of Ordovician to Devonian meta-sediments of the Cape Supergroup with its arcuate trend inherited from the structural grain of the orogenic Cape Fold Belt (Broad et al. 1996). Numerous structural characteristics of the Outeniqua sub-basins can be elucidated in terms of strike-slip faulting, and more so in the basins closest to the Agulhas-Falkland Fracture Zone (AFFZ; Broad et al. 1996). In addition, it has also been suggested that inversion tectonics due to periodic movement on the AFFZ contributed significantly to the structure of the basins (Broad et al. 1996). The Basin is a sub-basin of the Outeniqua Basin that covers an area of $18,000 \mathrm{~km}^{2}$ beneath the Indian Ocean on the southern South African Coast, southeast of Cape Town and west-southwest of Port Elizabeth (Turner J.R. et al. 2000). The geology comprises Upper Jurassic, Lower Cretaceous (Synrift continental and marine strata) and Cretaceous and Cenozoic (post-rift divergent margin strata).

The Bredasdorp Basin is a south-easterly trending basin which formed along with other sub-basins of the larger Outeniqua Basin, during the break-up of Gondwana along the Agulhas-Falkland Fracture Zone. Van der Merweet al. (1992), points toward evidence for high tectonic inversion within the basin. The basin contains two syndrift phases of sedimentation. The first phase (syndrift 1) of sedimentation is an unconformity which formed during tilted and can be dated to the early Jurassic period. The blocks are faulted with deep marine sediments underlying shallow marine sediments. The second phase (syndrift 2) contains deep water marine sediments found over tilted fault blocks; and indicator of rapid subsidence and wide spread flooding.

Deposition of highstand shelf deposits (biogenic clays, glauconitic clay and sands) occurred during the Tertiary period. These sediments were derived from erosion of the Agulhas Arch flanks due to uplift in the Late Cretaceous period, which concluded in the Early Miocene period (McMillan et al. 1997). Unconformities in the Holocene and Late Pleistocene overlay the Miocene strata which mark several type-1 sequence boundaries that can be seen in the chronostratigraphic log in Fig. 2 (McMillan et al. 1997). Two synrift phases are displayed, the first from the Early Jurassic period (157.1 Ma) to the Lower Cretaceous period $(121 \mathrm{Ma})$ the second being a much shorter synrift phase within the Hauterivian, which was separated by the first Type-1 Unconformity (1 At1).

McMillian et al. 1997 stated that break-up in the east caused dexteral trans-tensional stresses which gave rise to normal faulting in the northern Agulhas-Falkland Fracture Zone. Faults between the Agulhas Arch and the Infanta Arch trend northwest to southeast. This normal faulting resulted in graben and half-graben basins (Brown et al. 1995; McMillan et al. 1997). During the rift phase, the Bredasdorp Basin was sourced from provenances in the north and northeast comprising slates and orthoquartzites eroded from the Cape Super group as well as sandstones and shales from the Karoo Super group (McMillan 


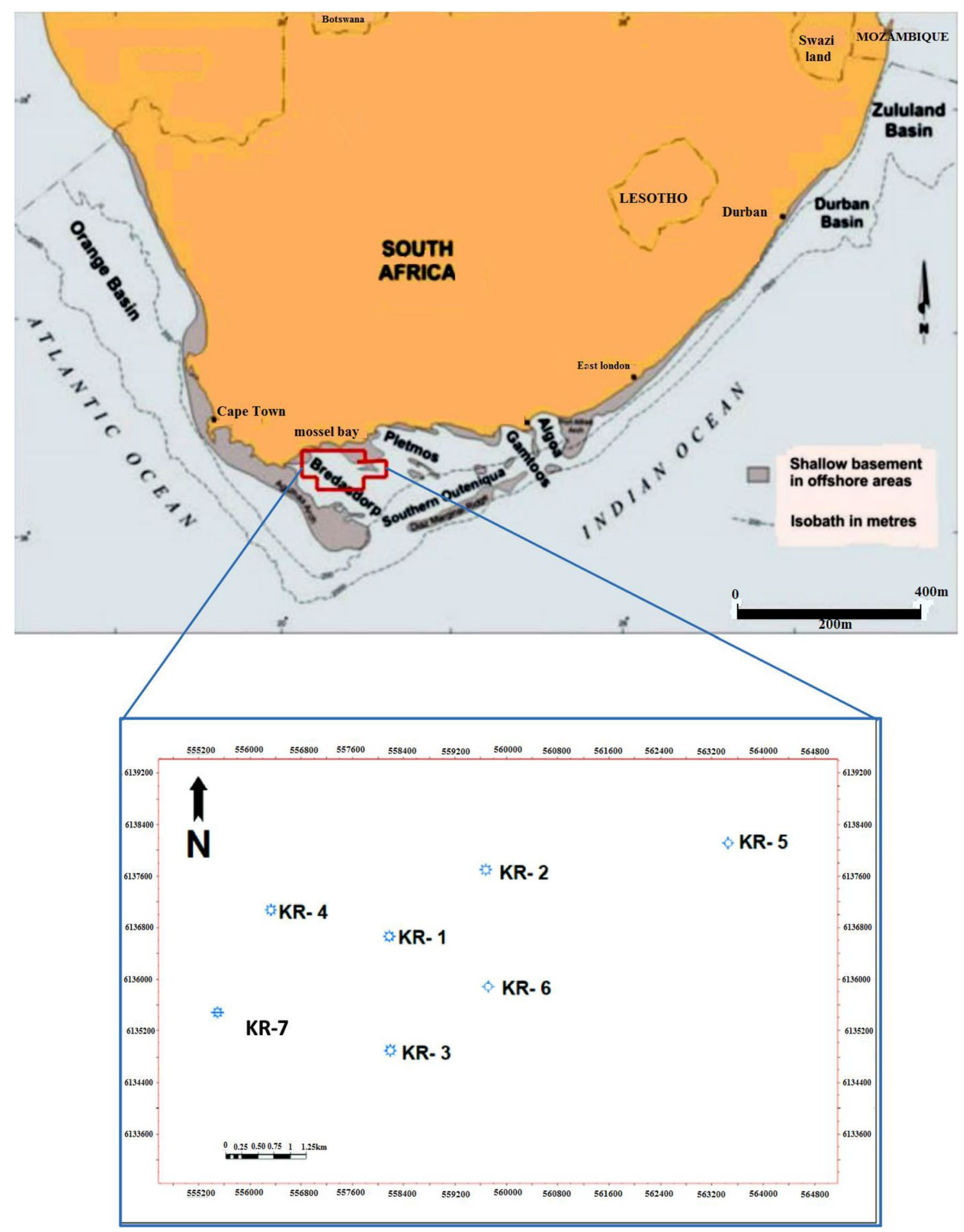

Fig. 1 Map showing the location of KR field, Bredasdorp Basin (modified after Petroleum South Africa brochure)

et al. 1997). A drop in sea level between the period of 103-112 Ma, resulted in material being eroded from highstand shelf sandstones, which were transported into the Centre of the basin by turbidity currents from west to southwest (Turner et al. 2000). These sediments formed "stacked and amalgamated channels and lobes" (Turner et al. 2000), which include fan lobes of a coarseningupward nature with reservoirs consisting of channel deposits characterized by fining-upwards (Turner et al. 2000). The Channels dominate the western to southwestern area 


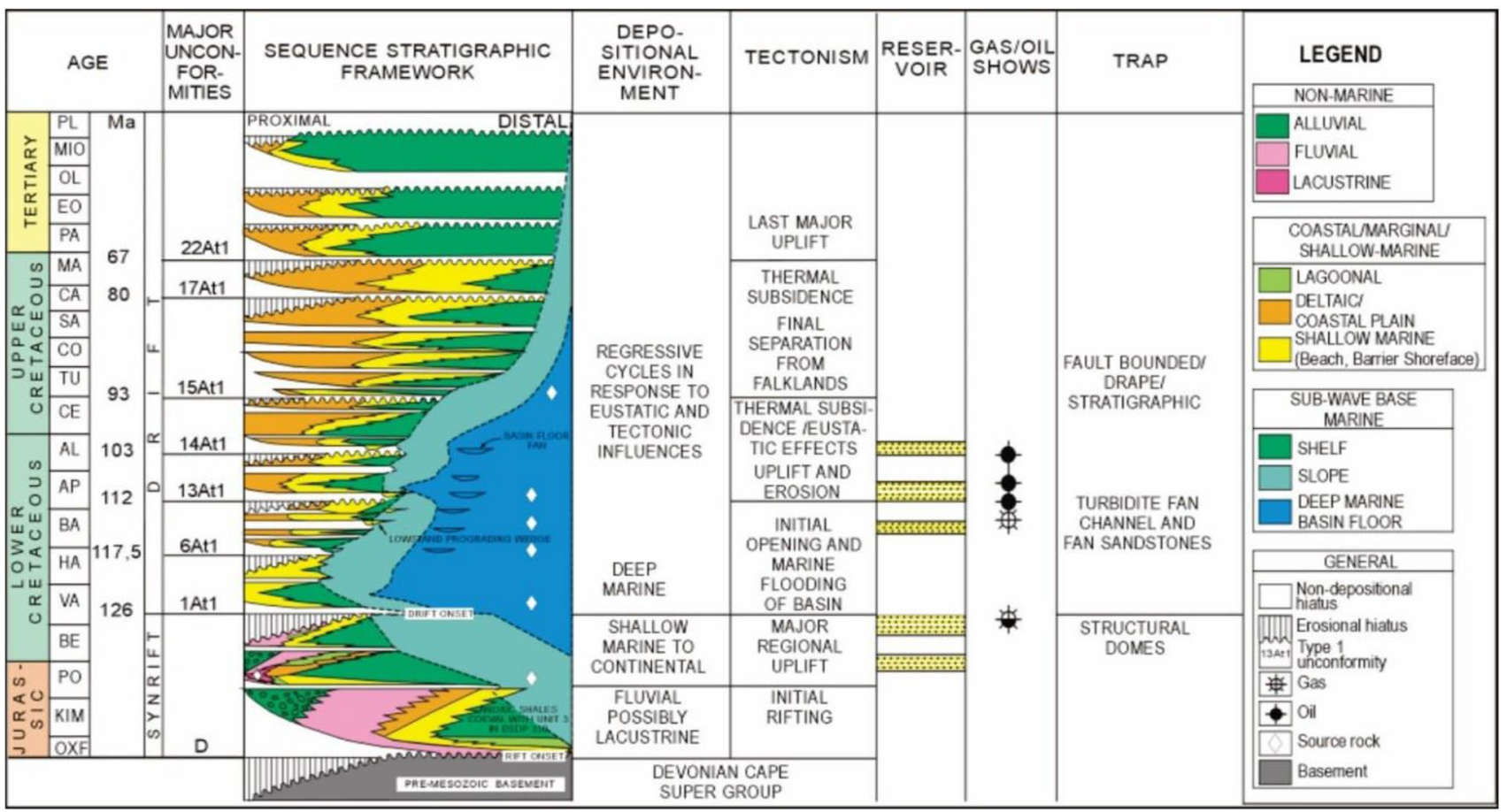

Fig. 2 Chronostratigraphy of Bredasdorp Basin (Petroleum Agency South Africa, 2005)

whereas the fan lobes are dominant in the eastern parts of the basin (Turner et al. 2000).

The present thermal gradient of the Bredasdorp Basin lies between $35-49^{\circ} \mathrm{C} \mathrm{km}^{-1}$ (Davies 1997). Temperature reduction during the Late Cretaceous period was due to reduced heat flow and subsidence after rifting. Africa migrated over a mantle plume during the late Cretaceous to early Tertiary periods, causing regional uplift which increased heat flow into the Bredasdorp Basin. Prior to $\sim 80 \mathrm{Ma}$, temperatures within the basin increased at a rate of greater than $3^{\circ} \mathrm{C} / \mathrm{Ma}$. Sedimentation rates decreased at about $\sim 80$ to $\sim 55 \mathrm{Ma}$, resulting in an average temperature rate drop of $<0.3{ }^{\circ} \mathrm{C} /$ $\mathrm{Ma}$ (Early Tertiary) which increased again during the Miocene to Pliocene periods (Davies 1997). Oil bearing source rocks of the Turonian saw a temperature increase of $\sim 10^{\circ} \mathrm{C}$ between $\sim 80$ to $\sim 55 \mathrm{Ma}$ (Davies 1997). Migration of formation waters from the southern Outeniqua Basin into the Bredasdorp Basin increased the temperatures by $\sim 20^{\circ} \mathrm{C}$. Early burial, hotspot transit and a hydrothermal event affected the maturation of Aptian and older formations. (Davies 1997).

Regional pressure studies on the basin were based mainly on data from Cretaceous reservoirs which indicate three pressure regimes (Winter 1981; Brink and Winters 1989; McAloon et al. 1990; Larsen 1995). A normally pressured zone down to $3000 \mathrm{~m}$ (Davies 1988); a second zone associated with thick source rocks (mainly 13A Aptian), in which equivalent mud weights ( $\mathrm{MW}_{\text {equiv }}$ ) are as high as $1.15 \mathrm{psi} /$ $\mathrm{ft}$; and a third zone where high overpressures are developed
(> 3000psi above hydrostatic). These pressures as recorded from RFT and DST readings are also estimated from petrophysical calculations (Verfaille 1993).

Compression in the Mid-Jurassic period, which is probably synonymous with early separation of the Falkland Plate, affected all offshore basins (Van der Merwe and Fouché 1992). As a result, uplift and erosion of Palaeozoic metasediments and Karoo sedimentary rocks occurred (Rowsell and De Swardt 1976). The second phase of compression happened during the Hauterivian period and could be related to the impact of the Falklands plate on the south coast of Africa. This resulted in an angular unconformity at horizon 5At1, which is the product of major uplift and erosion (Davies 1997). Shortly after the deposition of Albian 14A, a third phase of compression occurred. This formed the central basin structural highs. Davies, 1997 stated that this phase of compression is probably related to the passage of the eastern end of the Falkland Plate past the Agulhas Arch.

The K-R reservoir comprises the synrift, Berriasian-Valanginian (Lower Cretaceous) Upper Shallow Marine (USM) Sandstone, which is defined seismically by the Top Upper Shallow Marine (TUSM). The Base Upper Shallow Marine (BUSM) horizon is poorly defined and no intra reservoir horizons are seismically mappable. Several other seismic horizons have been mapped in the reservoir overburden: 1At1, 6At1, 8At1, 13At1, which can be seen in Fig. 2. The 1At1 and 6At1 are known to be unconformable indicating local erosion downwards into the USM, especially along the southern flank of the 
field and possibly on the western and eastern flanks in the saddle separating KR-5 from the K-R structure. The K-R structure is known to be only partly dip-closed and is highly compartmentalised by faulting. Normal faults and some reverse faults occur but some strike-slip movements may also have occurred, although they are difficult to identify. Most of the faults in the field trends are either north-northwest to south-southeast (NNW-SSE) or northwest-southeast (NW-SE) as shown in Fig. 3. The USM reservoir thickens markedly into a major east-west trending regional boundary fault to the north of the K-R Field.

\section{Materials and methods}

To construct a geomechanical model of seven wells in the K-R field, it is essential to use accurate values of elastic parameters and in situ rock strength. These include the Uniaxial (or unconfined) Compressive Strength (UCS), Friction angle ( $\phi)$, Young's modulus $(E)$ and Poisson's ratio (PR). The vertical stress (in situ) is the result of the weight of rock per unit area above each point in the earth. Therefore, the magnitude of vertical stress can be derived by integrating the bulk density log (RHOB) for each well. The integration is expressed in Eq. 1 (Zoback et al 2003).

$\sigma_{v}=\int_{0}^{z} \rho g \mathrm{~d} z$ where $\sigma_{v}$ is vertical stress, $\rho$ is rock density, $g$ is gravitational acceleration and $z$ is the depth.

The original obtained from density logs were first corrected by the use of an equation that relates the density and velocity obtained from sonic log since the latter is not affected by geometry effects (Santana 2010), and then integrated into Eq. 1.1. This is a highly important step as the accuracy of $\sigma_{v}$ is dependent on the density $\log$. The pore pressure for each well was calculated using the Eaton method. Eaton (1975) defined pore pressure as a function of overburden pressure, hydrostatic pressure and an observed parameter/normal parameter ratio. The observed parameter could be the sonic travel time, resistivity or $d^{\prime}$ exponent (a drilling parameter). Originally established in the Gulf coast, the Eaton equations have been used worldwide as the exponents may be adjusted based on the environment as expressed below (Eaton 1975):

$$
\begin{aligned}
& P=S-(S-\text { hyd })\left[\frac{R_{\mathrm{sh}} \text { observed }}{R_{\mathrm{sh}} \text { normal }}\right] \\
& P=S-(S-\text { hyd })\left[\frac{\Delta_{t} \text { observed }}{\Delta_{t} \text { normal }}\right] \\
& P=S-(S-\text { hyd })\left[\frac{d c-\text { observed }}{d c-\text { normal }}\right],
\end{aligned}
$$

\section{Top TUSM - Structural Depth Map}

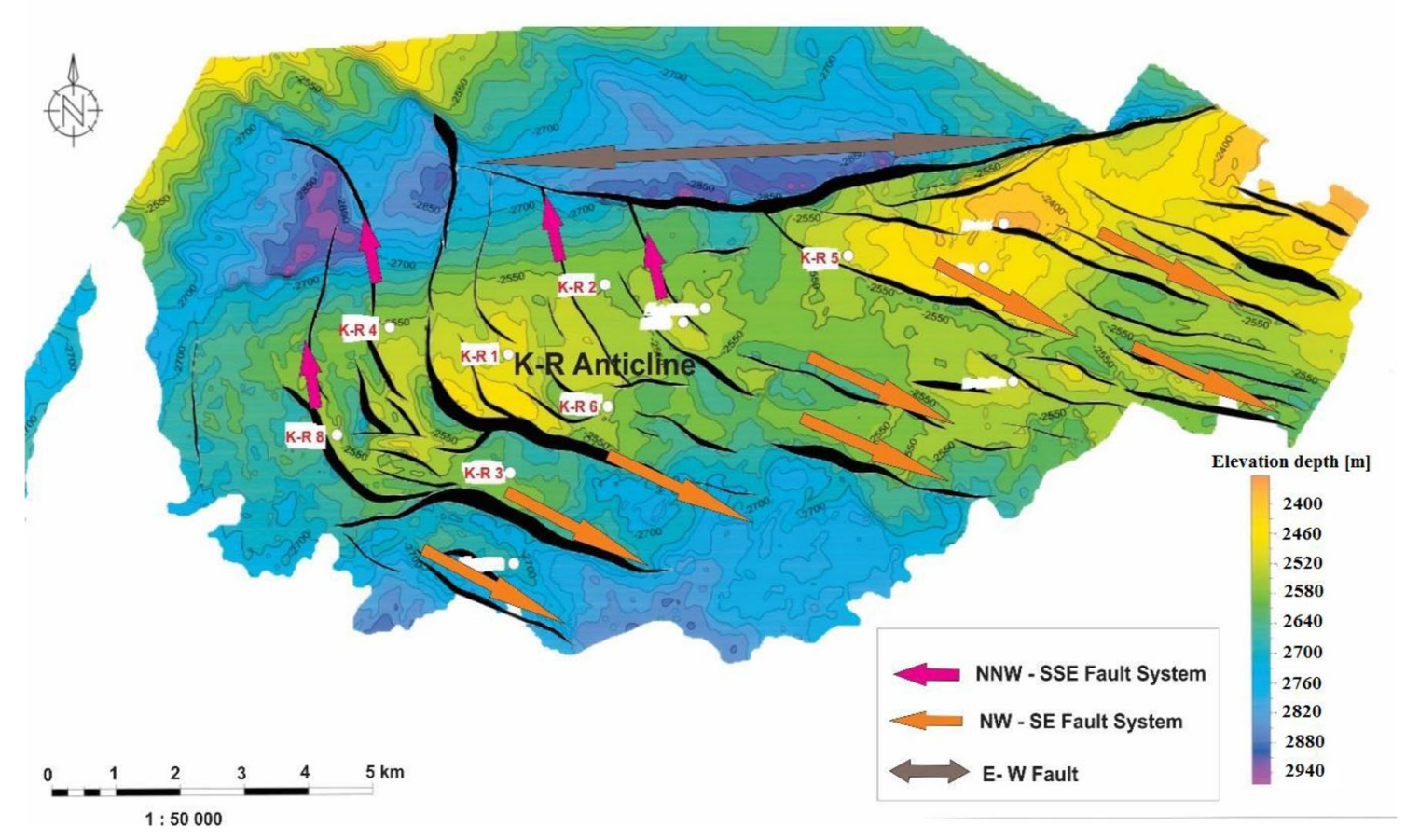

Fig. 3 A structural depth map showing the fault system of the KR-Anticline at TUSM 
where $P$ is pore pressure, $S$ is the overburden, hyd is the hydrostatic pressure ( $0.44 \mathrm{psi} / \mathrm{ft}), R_{s h}$ is the shale resistivity, $\Delta_{t}$ refers to the sonic slowness and $d c$ denotes the $d^{\prime}$ exponent. The difference between the equations is that Eq. 2 used the resistivity of shale as an input parameter, while Eq. 3 used the sonic travel time. Equation 4 was used to calculate pore pressure because the input parameter used is from RFT which is more reliable.

No reservoir overpressure exists in the K-R field, wherever overpressure is mentioned in the driller's report. It is due to buoyancy effects which occur when hydrocarbons migrate into a tilted reservoir. As the hydrocarbon column height grows, the top of the reservoir begins to experience elevated pressure. Tests performed on cores provide more accurate static properties for modelling than dynamic properties calculated from log data. However, no laboratory strength tests were performed on the cores for the K-R field and thus empirical calculation had to be done using well log data. Once all geomechanical calculations were undertaken using Microsoft Excel, they were then imported onto the Drillworks ${ }^{\circledR}$ software for modelling. The following is a succinct description of the software used to complete the modelling. The data available for calibration are minimal and the mud weight used to drill the well was the main source. All calibrations were adjusted on Microsoft Excel and then imported onto the Drillworks ${ }^{@}$ software. The resulting geopressure gradient's post-calibrations are shown in Fig. 6.

Fracture gradient is "the pressure gradient that will cause fracture of the formation" (Rocha et al. 2004). Hence, if the fracture gradient is exceeded, the formation will fracture resulting in a mud loss. Along with pore pressure gradient, the fracture gradient is one of the most important aspects to be considered during the planning and drilling phase. Methods of fracture gradient estimation are generally derived from rock mechanics theories or simplified methods which may lack accuracy in representing underground rock conditions (Rocha et al. 2004). Numerous published methods for fractured gradient are available and can be categorized as either "direct" or "indirect" methods (Rocha et al. 2004). Direct methods give a measurement of pressure required to fracture the rock as well as propagating the resulting fracture. These direct methods are generally based on leak off tests or extended leak-off tests which are common calibration test in the petroleum industry. The indirect methods are based on analytical or numerical models used to provide fracture pressure gradient along entire length of the well. These methods are generally applied for a specific field or area and the input data are often difficult to obtain. However, in this study we used the indirect and direct methods to estimate the fracture gradient, vertical stress and pore pressure gradients. The Eaton (1969) method for fracture gradient determination was used in this work because it utilizes more input parameters and the results are more reliable. The expression is given below (Eaton 1969):

$\mathrm{FG}=[v / 1-v] \times\left[S_{v}-P_{\mathrm{p}}\right]+P_{\mathrm{p}}$,

where $F G=$ fracture gradient (psi/ft), $V=$ Poisson's ratio, $S_{\mathrm{v}}$ $=$ vertical stress $(\mathrm{psi} / \mathrm{ft}), P_{\mathrm{p}}=$ pore pressure gradient $(\mathrm{psi} / \mathrm{ft})$.

The estimation of pore pressure gradient is imperative as uncertainties and inaccurate results may lead to formation damage, wellbore stability issues, kicks and the worst case scenario of a blowout. Knowledge of pore pressure throughout the well is paramount to drilling safely and efficiently as well as assessing potential risk factors, migration of formation fluids and seal integrity (Tang et al. 2011). Where the pore pressure of the formation is assumed to be almost equal to the theoretical hydrostatic head for the vertical well depth, the formation is considered to be normally pressurized (Bourgoyne Jr. et al. 1986). Thus, the normal pore pressure can be estimated using the hydrostatic gradient of that area.

Drillworks ${ }^{\circledR}$ - predict software provides reliable forecasts of pore pressure gradient and fracture gradient with several models and correlations available which are the basis for analysing the mud window. A major perk of the predict simulation is its capability to offer pre-drill, real-time as well as post-drill analysis to enhance drilling performances and to avoid difficulties throughout the entire drilling process. The pre-drill analysis assists in choosing the optimal mud weight setting and casing design depths for a successful well. If the pre-drill analysis turns out to be erroneous, the real time analysis allows the user to implement modifications to the pre-planned model to maintain an optimal drilling process. The post-drill analysis tools allow for an improved knowledge for the planning and drilling of future wells (Keaney 2005).

This software is a geomechanical analysis tool which allows the user to assess wellbore stability issues before and during drilling. Geostress may be used to plan the most suitable well path as well as to fine-tune and create the best mud weight design possible (Keaney 2005). In this study, the geostress tool has been used to investigate the safe wellbore trajectory and the safe mud window.

\section{Results and discussion}

Figure 4 presents an example of comparison of the original density $\log$ and result of the environmental corrected density log which shows a less erratic and more even distribution of density data. The vertical stress was calculated using both the original density and corrected density and plotted against depth to show variation (Fig. 5). The figure shows a vertical stress gradient using the original density of 0.9949 $\mathrm{psi} / \mathrm{ft}$, which represents $8159.29 \mathrm{psi}$, against a vertical 


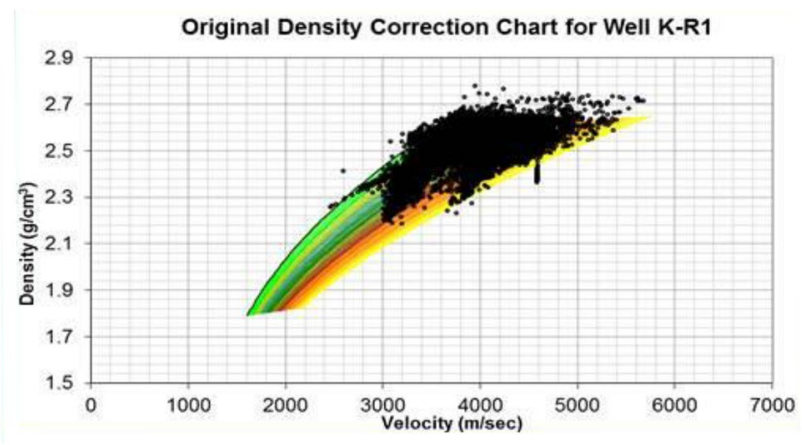

Corrected Density Chart for Well K-R1

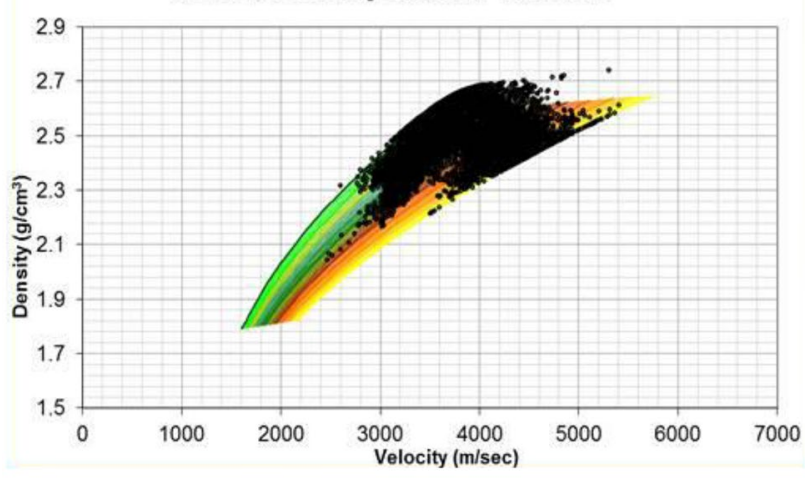

Fig. 4 Original and corrected density chart

stress gradient obtained from the corrected density log of $0.9887 \mathrm{psi} / \mathrm{ft}$ or $8108.44 \mathrm{psi}$; yielding a difference of $50 \mathrm{psi}$. Although this value may seem trivial, it may have a great impact on the limits of the mud window prediction since the vertical stress is incorporated in the empirical calculations of pore pressure gradient and fracture gradient. This could in turn have a domino effect on wellbore stability and the cost associated with it.

\section{Well KR-1}

The resulting geopressure gradient's post-calibrations are shown in Fig. 6. The friction angle (FA), cohesive strength (CS), and un-compressive strength (UCS) show a general increase with depth, mainly towards the well's total depth (TD). Graphs showing the safe drilling mud window at TUSM and BUSM are shown in Fig. 8. A wider mud window is observed at BUSM, which implies that at the bottom of the reservoir, wellbore trajectory is central to wellbore stability issues.

\section{Well KR-2}

Well KR-2 has the most calibration sources; two leak-off tests were performed at depth intervals of 301-314 and 1425-1428, respectively. Well KR-2 was drilled predominantly with a mud weight of $9 \mathrm{ppg}$. The geopressure curves after calibration are shown in Fig. 6. The estimated rock mechanical properties obtained through correlations are shown in Fig. 6. A similar trend to well KR-1 is observed for FA, CS and UCS, that indicates an increase with depth, especially close to the TD. Graphs showing the safe drilling mud window at depths of 2593 and $2859.5 \mathrm{~m}$, respectively, are shown in Fig. 8. For this well, a more constricted mud window is observed at the top of the reservoir. Wellbore trajectory is central to wellbore stability issues.

\section{Well KR-3}

Well KR-3 has the most calibration sources and was drilled predominantly with a mud weight of $9 \mathrm{ppg}$. At depths of approximately $2451-2563 \mathrm{~m}$, an elevation of pore pressure exists and the mud weight used to drill this section is lower than the pore pressure gradient. A resulting increase in fracture gradient is observed, which is shown in Fig. 6. This pore pressure increase is observed in the over pressured shale just above the sandstone unit. The mechanical properties of the rock for well KR-3 are presented in Fig. 7. The friction angle has an erratic trend and the trends for CS and UCS show a more pronounced increase towards the TD when compared to wells KR-1 and KR-2. The safe drilling mud window for well KR-3 at TUSM and BUSM, together with the equivalent circulating density (ECD) is shown in Fig. 8. A larger mud window is shown towards the top of the reservoir. The hemisphere plots in Fig. 9 vary slightly to that of the previous wells. This is mainly due to well KR-3 having the highest overburden gradient at TUSM (19.23 ppg) for the K-R field as well as higher friction angles than well KR-1 and $\mathrm{KR}-2$, resulting in greater mud weight variation.

\section{Well KR-4}

The geopressure gradient curve following calibration is shown in Fig. 6. The main calibration source for this well is the actual mud weights recorded whilst drilling. Elevated compartments of pore pressure are observed at various depth intervals, resulting in high fracture gradients. The mechanical properties of the rock that are shown in Fig. 7 show similar trends to previous wells. The cohesive strength and unconfined compressive strength show a pronounced increase at depths of approximately $2495 \mathrm{~m}$ up to the TD of the well. The safe mud window plots for the top and bottom of the reservoir are shown in Fig. 8. The top of the reservoir for well KR-4 shows a slightly more constricted mud window than observed at BUSM. The lower hemisphere plots shown in Fig. 9 are almost identical to that of well KR-1. This is due the values of overburden gradients and horizontal stresses being similar.

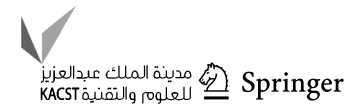


Fig. 5 Example of graph showing vertical stress gradient before and after density correction with depth for well KR-1

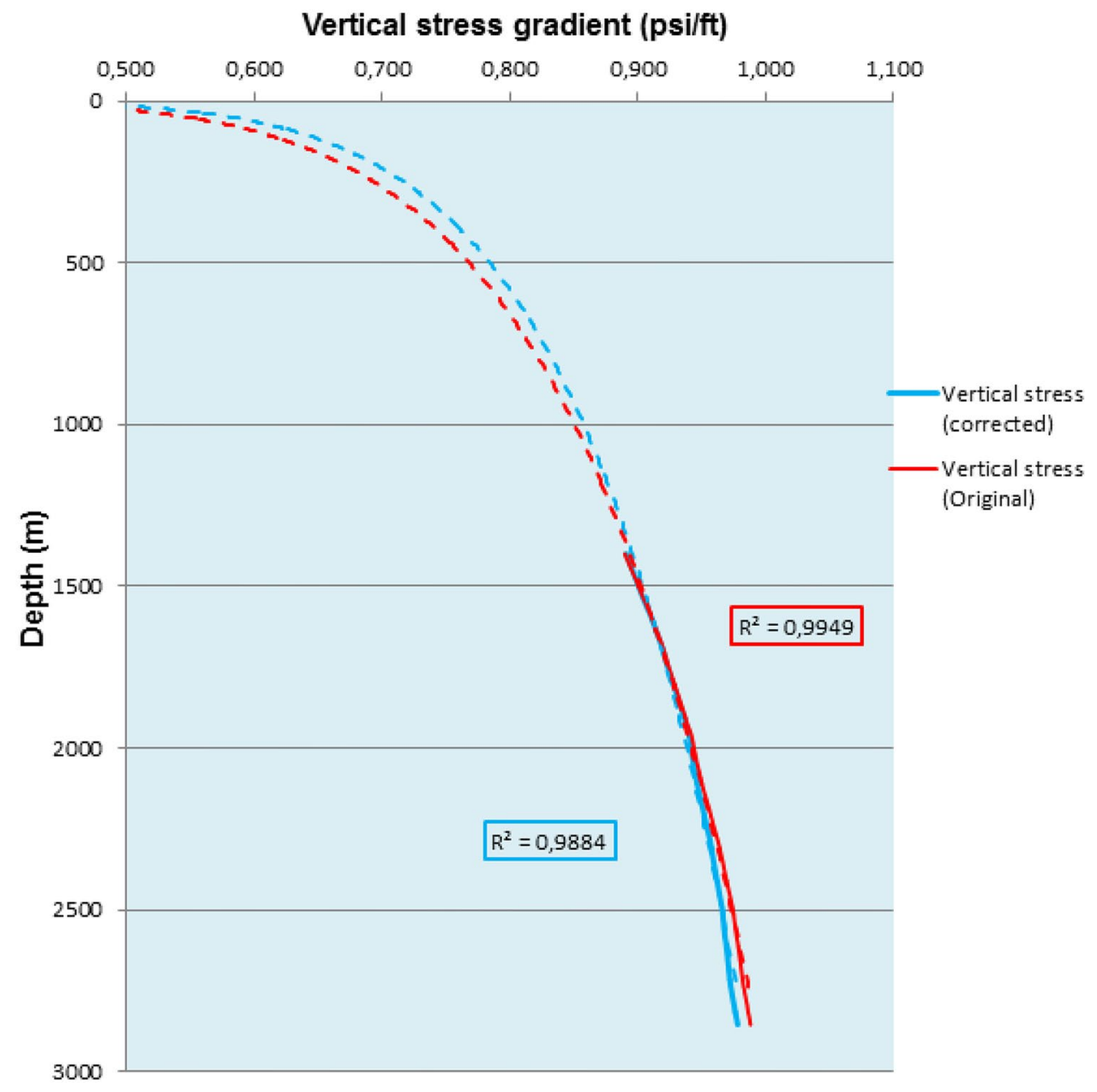

\section{Well KR-5}

The geopressure gradient curve after calibration is shown in Fig. 6. The main calibration sources for this well are the actual mud weights recorded whilst drilling. Elevated compartments of pore pressure are observed at various depth intervals, resulting in high fracture gradients. The mechanical properties of the rock shown in Fig. 7 displayed similar trends to previous wells. The cohesive strength and unconfined compressive strength shows a marked increase at depths of approximately $2504 \mathrm{~m}$ up to the TD of the well. The safe mud window plots for the top and bottom of the reservoir are shown in Fig. 8. The top of the reservoir for well KR-5 shows the narrowest safe drilling mud window for the K-R Field. The lower hemisphere plots are shown in Fig. 9. This well shows a contrast to well KR-3 as it has the lowest overburden gradient value for the entire field.

\section{Well KR-6}

The geopressure gradient curve after calibration of well KR-6 is similar to previous wells, with few calibration sources being available. A high pore pressure compartment can be observed at approximate depths of 2412-2572 m, resulting in an elevated fracture gradient at that depth (Fig. 6). The rock mechanical properties displayed two erratic sections of high cohesive and unconfined compressive strengths observed at depths of approximately 1982-2124 and $2541 \mathrm{~m}$ to the TD of the well (Fig. 7). The safe mud window plots for the top and bottom of the reservoir are shown in Fig. 8 showed the bottom of the reservoir for well KR-6 a much larger safe drilling mud window.

The lower hemisphere plots at TUSM and BUSM are shown in Fig. 9.

\section{Well KR-7}

This is the most distinct well within the K-R field. The geopressure gradient curve's post-calibration presented in Fig. 3 shows a complete profile of drilling mud weights along the well trajectory and a greater degree of separation between the pore pressure and fracture gradient curves. The rock mechanical properties shown in Fig. 7 presented a similar trend of increased cohesive and unconfined compressive 
Fig. 6 Modelled geopressure gradients for well post-calibration

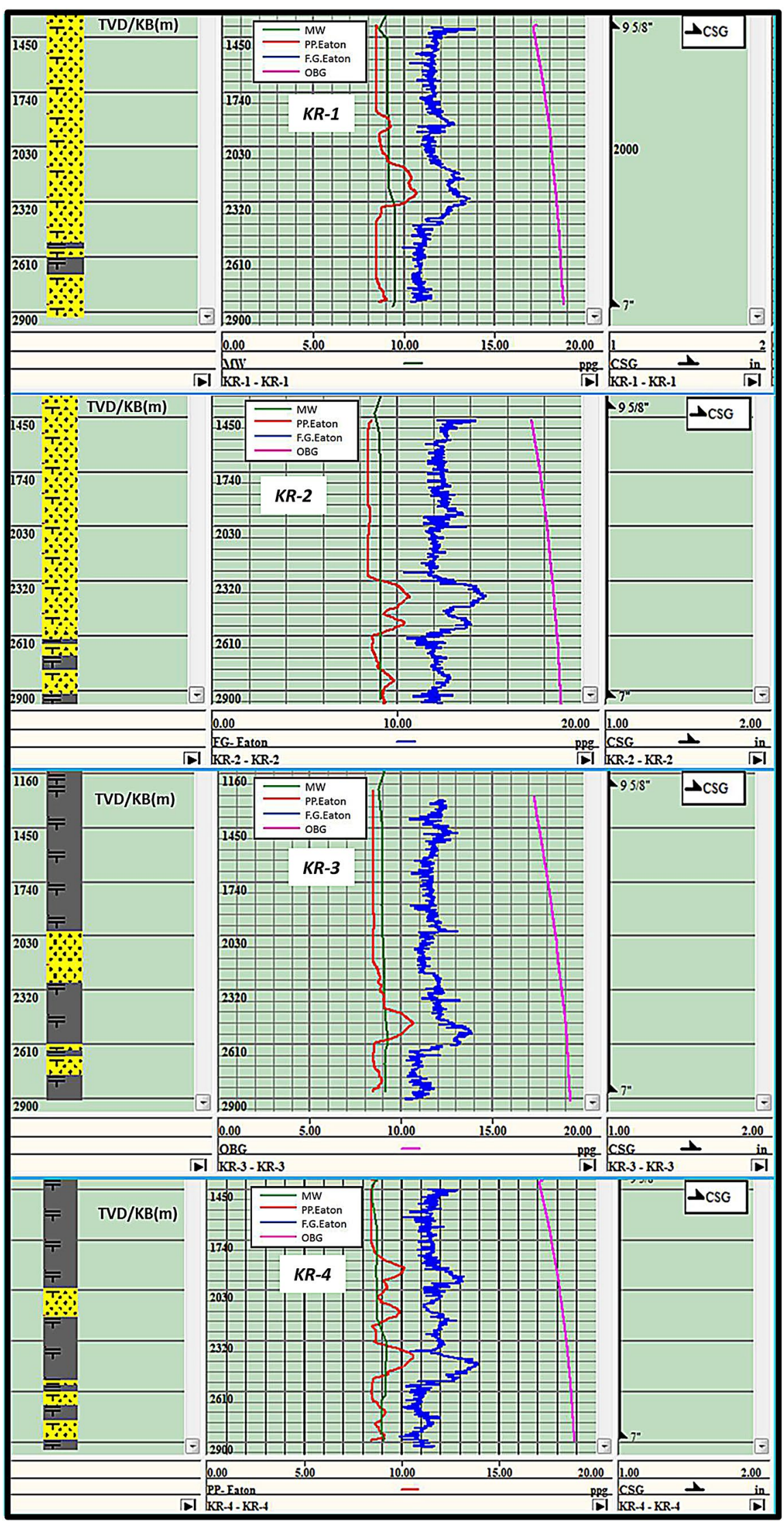

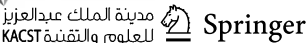


Fig. 6 (continued)

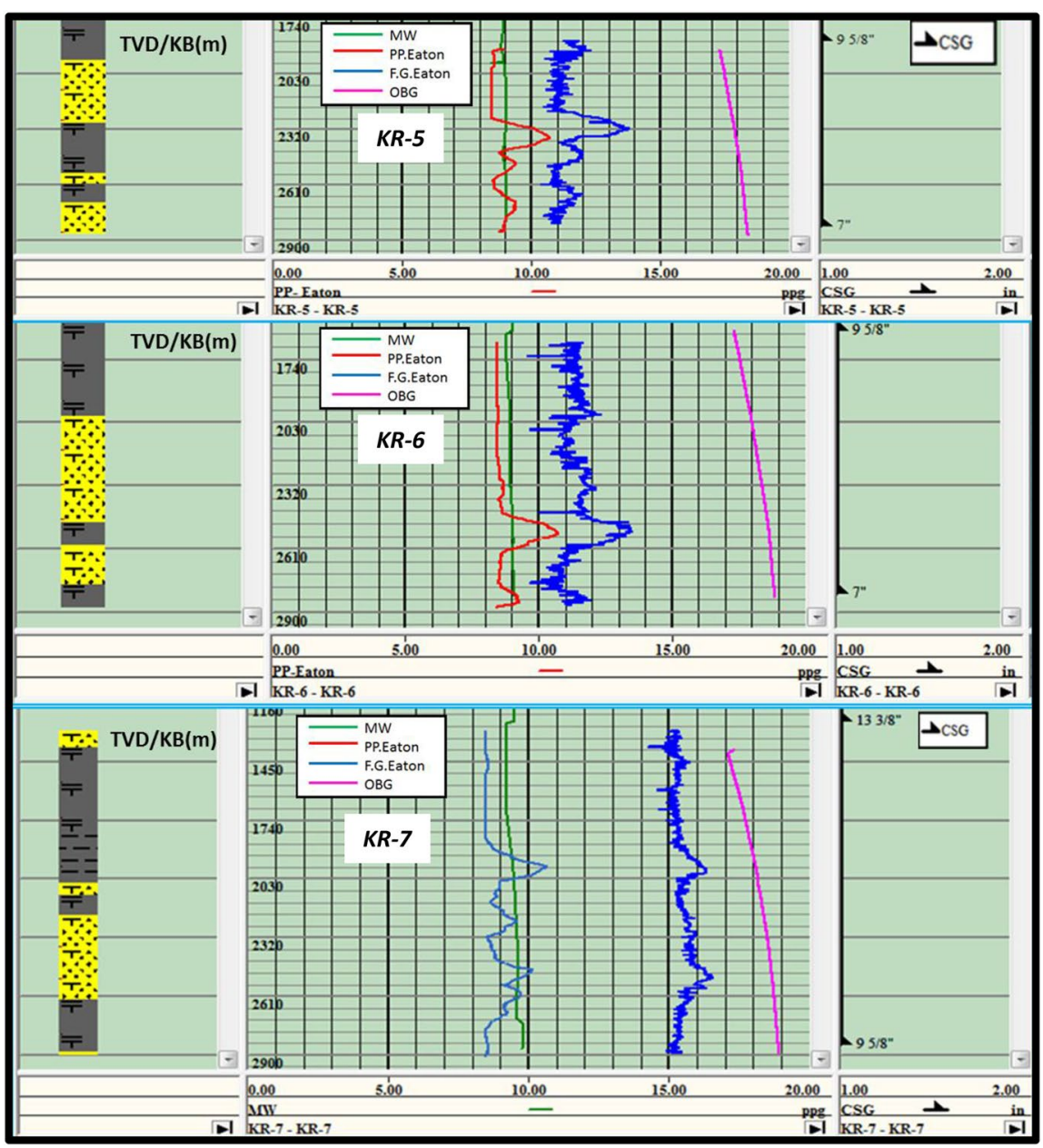

strength towards the TD of KR-7, as noted in previous wells. This increase starts at approximately $2520 \mathrm{~m}$. The safe mud window plots for the top and bottom of the reservoir in Fig. 8 have the largest mud window for the K-R field at both TUSM and BUSM. The lower hemisphere plots shown in Fig. 9 differ from all previous wells. This well shows the highest minimum and maximum horizontal stress for the K-R Field.

\section{Discussion}

The study was based predominantly on well log data and well reports for all seven wells. In areas where there is no well data, correlations have to be made to predict how the stress gradients will behave in the K-R field. For these correlations, petrophysics was used extensively to derive geomechanical parameters which were modelled on the Drillworks ${ }^{@}$ software package. The drilling data available from each report are used as calibration sources for geopressure. Knowledge of formation pressures is imperative to drilling; however, in areas where no drilling has occurred, well planners are essentially drilling "blind". Seismic data that are available may not be ideal as it may inherently imply that geopressure gradients are based on correlations. Nonetheless, in areas of scarce data sources, correlations that best fit the data set have to be used. The geomechanical model that was built is a prediction of how geopressure will behave in the K-R field, and is to be used when planning future wells in the area.

When calibrating the modelled pore pressure gradient and fracture gradient, the normal compaction trend line was shifted for all wells for the calibration points and geopressure gradients to coincide. This indicated that the values used to create the normal compaction trend lines were too low at the end point. Thus, the formation is less compacted than initially assumed.

The shifting of the normal compaction trend lines to higher values resulted in a decreased margin between the trend lines and the measured sonic logs. Inevitably, the values derived from Eaton's sonic method for predicting pore pressure yielded lower values, as deduced from Equations 1.4. The reduction in pore pressure values influenced a resulting decrease in fracture gradients values which are linked by the Eaton fracture gradient method-Eq. 1.6. 
Fig. 7 Rock mechanical properties for wells

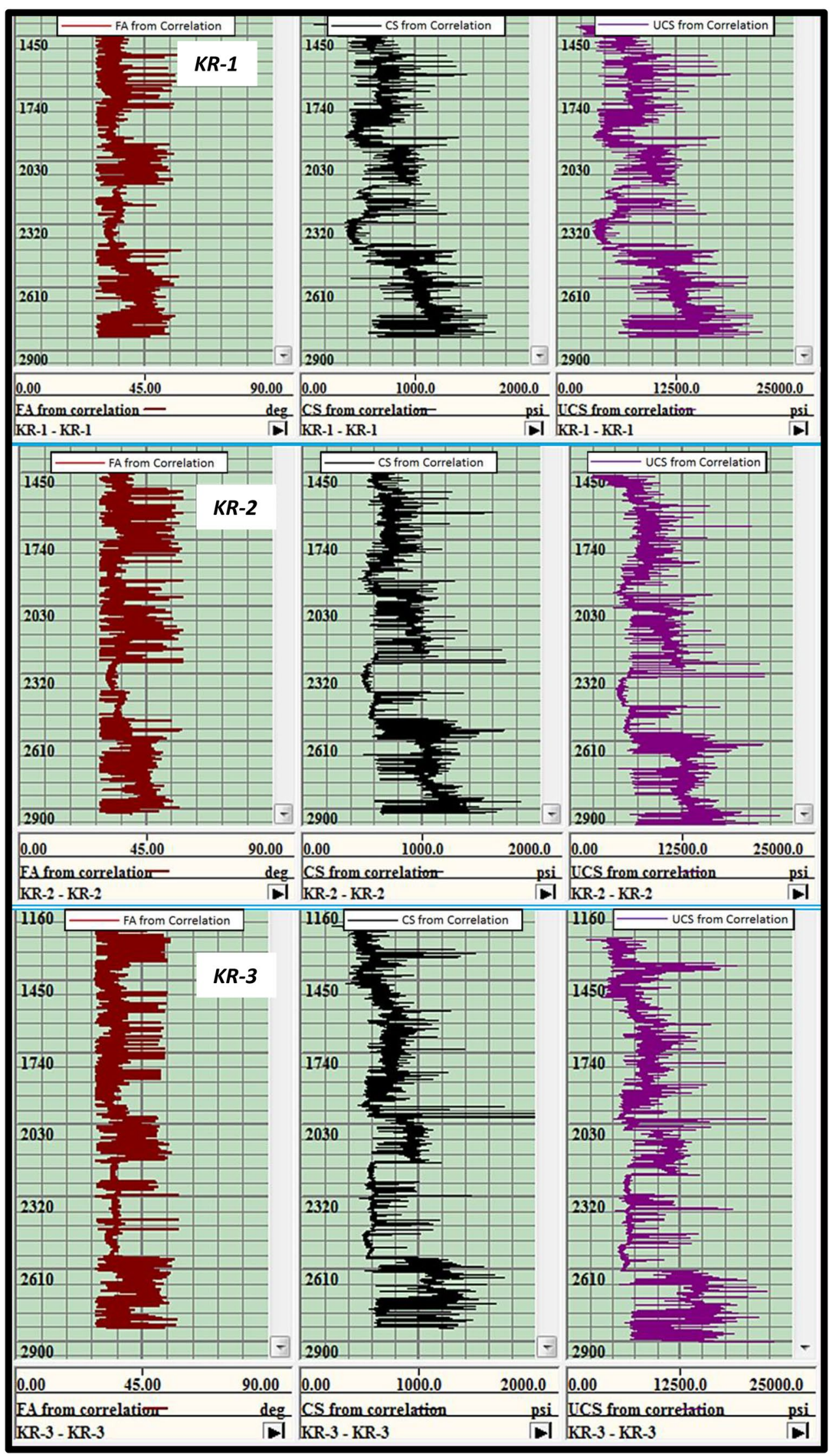


Fig. 7 (continued)

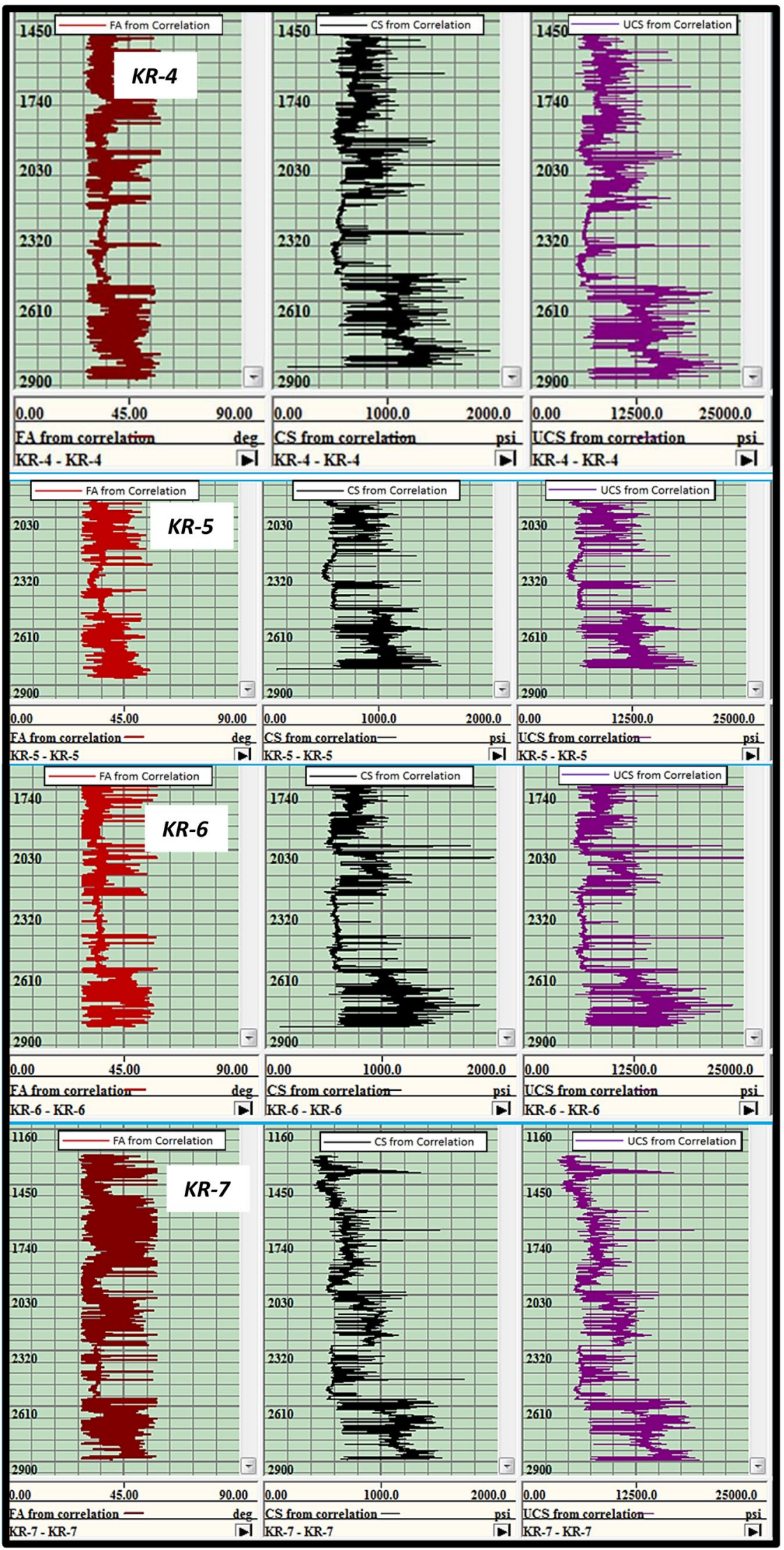


Fig. 8 Safe mud windows for TUSM and BUSM
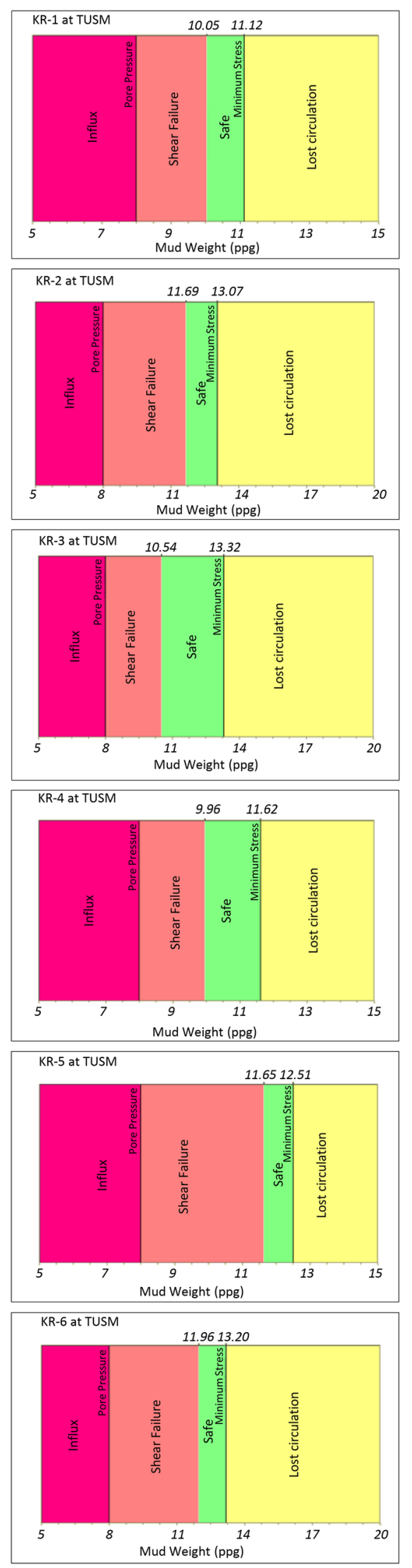
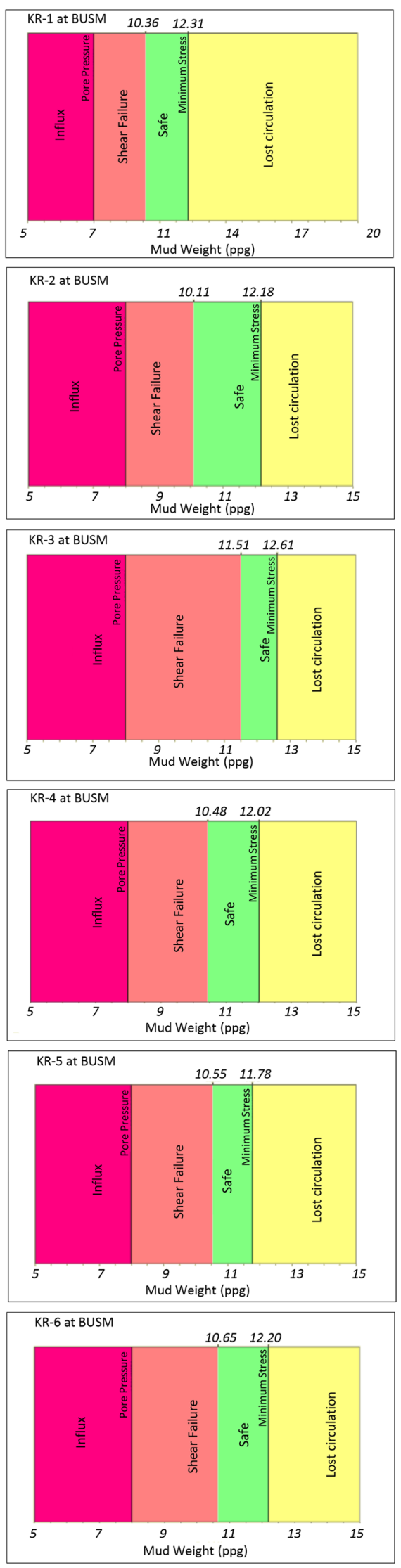

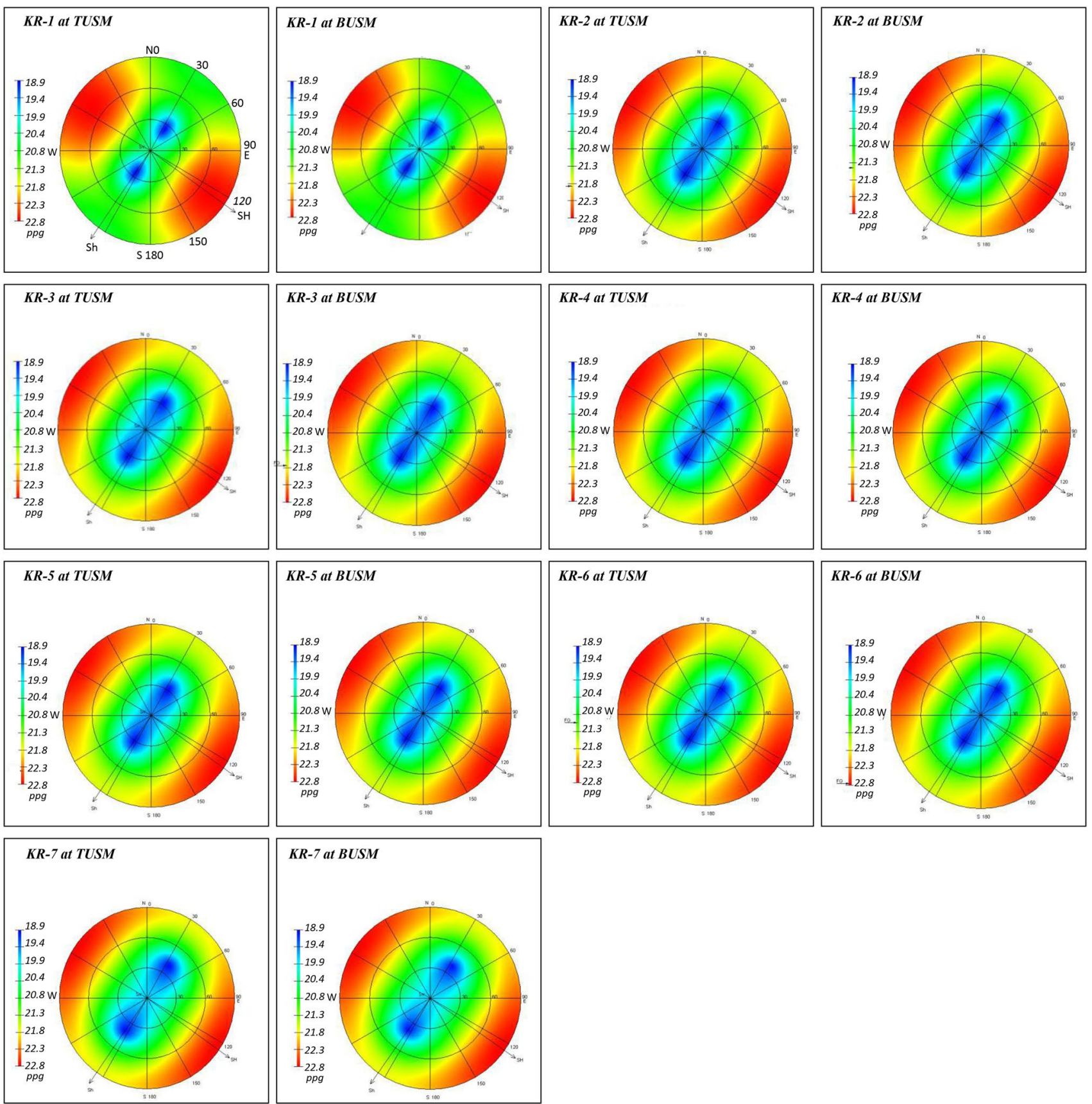

Fig. 9 Lower hemisphere plot for wells at TUSM and BUSM

Well KR-3 shows a larger drop in pressure gradient than the other wells from the top to the bottom of the reservoir; the pore pressure has been reduced from $9.6 \mathrm{ppg}$ to $8.5 \mathrm{ppg}$. The operational drilling windows post-calibration shows a similar trend. For depths to $2600 \mathrm{~m}$ the drilling window is fairly wide and at depths deeper than $2600 \mathrm{~m}$ the drilling window becomes more constricted. This is the case for all wells except well KR-7 where the drilling window remains wide up until the true depth of the well. It is important to note that all KR-wells have close to zero inclination; in an inclined well, the drilling mud window will be narrower.

The mechanical properties of the rock for the seven wells show roughly the same trend. The friction angle shows an average range between $35^{\circ}-40^{\circ}$ for all wells. Although high, these values are still indicative of sandstone (Horsrud 2001). The cohesive strength and unconfined compressive strength values vary, depending on the sandstone. The values produced within the reservoir are between ranges of 
9000-14,000 psi for unconfined compressive strength and 800-1200 psi for cohesive strength.

The safe wellbore trajectory analysis displays the same trend for all KR-wells. The hemisphere plots (Fig. 9) show a greater variation on the mud weight in the direction of maximum horizontal stress, thus showing the need for lower mud weight when drilling in the minimum horizontal stress direction, NE-SW. This is due to an assumed value of 1.02 for the horizontal stress ratio. The higher the ratio, the greater the difference will be regarding mud weight variation to horizontal stress direction.

The hemisphere plots (Fig. 9) show the maximum horizontal stress azimuth to be $125^{\circ}$. To depict a realistic value, the strike direction of drilling induced fracture can be used to provide an estimation of maximum horizontal stress direction. For this model, the maximum horizontal stress direction was assumed from the regional strike direction of faults on the structural depth map shown in Fig. 2.

When modelling on the Drillworks ${ }^{\circledR}$ software, the model must be compressed to reflect the current formation depth intervals, which allows the well planner to sufficiently determine the mud window. The software allows for flow rate simulation and hydraulics to be run, which results in the equivalent circulating densities and downhole pressures. For this model, the actual mud weight values recorded whilst drilling each well are displayed alongside the simulated geopressure gradients.

The shear failure gradient has not been calculated for this model. This parameter is generally used to ascertain when a rock experiences shear failure. Different models to calculate rock mechanical properties generally have a pronounced effect on the shear failure gradient, and thus, create a lot of uncertainty in the model. The empirical shear gradient values can be validated by observing wellbore cutting where instability issues occurred. The shape and size of the cuttings provides us with tangible information as to whether or not the mud weight used exceeded the shear failure gradient. Any geomechanical model must be history matched and calibrated to minimise the uncertainty. Also, a high number of off-set wells used to build a model will yield a more accurate prediction. However, there are inherent uncertainties during the process of drilling a well; operational observations and drilling incidents that need to be acted on, resulting in changes to pre-drilled safe mud window estimates.

In the geomechanical model, pre-calibration is based only on log data and information from well and driller's reports. The geopressure gradients are dependent on each other, and thus, discrepancies in the log data may result in inaccurate values. Quality checking the $\log$ data is imperative to ensure that all values are in alignment with historically validated measurements. A typical example of this is the density of the formations. If these values have been estimated incorrectly, the overburden gradient will be erroneous, which will have a knock-on erroneous effect for pore pressure gradient and fracture gradient estimations. This scenario occurs with the sonic log as well, due to the fact that this particular log is used as the porosity log. When normal compaction trend lines are generated on erroneous sonic datasets, the result is inevitably an incorrect pore pressure estimation. It is quite clear that geopressure gradients in this case, are incredibly sensitive to well log data inaccuracies.

Having a fundamental knowledge of the whole cycle of data acquisition is pivotal in understanding the geomechanical model in its entirety. This means understanding geological data, seismic data, well log data as well as well completion and drilling reports. Confusion may arise when these sources of data are collected by different service companies, wherein they may be either represented differently, or the technical terminology may be different. It is also essential to have an understanding of the actual drilling process and what caused certain drilling incidents or stability issues to arise. Through merging the physical phenomena and operational observations with the theoretical model, a more correct canvas is painted allowing us to drill as safely and efficiently as possible.

\section{Conclusions}

The Bredasdorp Basin consists of several oil and gas fields, amongst which is the K-R Field. Using offset well data along with various calibration sources, a 2D geomechanical model was built, allowing for an estimation of the overburden gradient, pore pressure gradient and fracture gradient for future wells drilled in the field. A significant part of this model involves calibration which incorporates operational observations to fit the geopressure curves to actual drilling incidents. The current model that was built is quite a reliable estimate, and as previously mentioned, the inclusion of more offset wells will yield a more accurate prediction of the safe drilling mud window for the K-R field.

The 2D geomechanical model for the K-R field shows how the overburden gradient, pore pressure gradient and fracture gradient vary with depth. The pore pressure and fracture gradient values are of most relevance as they set the minimum and maximum limits for drilling a well safely. These geopressure gradients were calculated using the Eaton Method; for the upper shallow marine reservoir, these values range between 8.46 and $9.60 \mathrm{ppg}$ and $10.12-15.33 \mathrm{ppg}$, respectively. The modelled geopressure gradients shows a wider drilling mud window up to about $2600 \mathrm{~m}$, becoming slightly narrower as the depth approaches the TD of the wells. This is true for all wells except well KR-7, which subsequently is the most recent and best drilled well, in regard to washouts and wellbore failures. The mechanical 
properties of the rock show roughly the same trend, with increasing values towards the wells TD.

The importance of applying a density correction prior to any stress calculations has been demonstrated. Accurate density data have a direct effect on the vertical stress gradient which is ultimately linked to the pore pressure and fracture gradient. This model has been created in the hope that reliable drilling mud windows can be estimated for future wells in the K-R field area, thereby reducing drilling-related and wellbore stability issues, ultimately allowing for wells to be drilled safely and cost effectively.

To further validate the findings of this paper, we thus recommend that more wells and new wells should be added to either validate or invalidate the model. A 2D model is a good representation of geopressure gradients with depth of wells. However, stability issues are often in the form of 3D principal stress problems. If more data become available, a full-scale 3D geomechanical model may cover certain issues not addressed in this paper.

Acknowledgements We thank the Petroleum Company of South Africa (PetroSA) and Petroleum Agency of South Africa (PASA) for the provision of data used in this work. We also appreciate the support from the Halliburton Company for the software used. Our thanks also to $\mathrm{Mr}$ Leonardo of PetroSA for his contributions.

Open Access This article is distributed under the terms of the Creative Commons Attribution 4.0 International License (http://creativeco mmons.org/licenses/by/4.0/), which permits unrestricted use, distribution, and reproduction in any medium, provided you give appropriate credit to the original author(s) and the source, provide a link to the Creative Commons license, and indicate if changes were made.

\section{References}

Anderson EM (1951) The dynamics of faulting and dyke formation, with applications to Britain, 2 edn. Oliver and Boyd, Edinburgh

Bourgoyne AT Jr, Millheim KK, Chenevert ME, Young Jr. FS (1986). Applied Drilling Engineering. SPE Textbook Series

Brink GJ, Winters SJ (1989) Overpressure study of the Bredasdorp Basin. SOEKOR unpubl. Rept., pp. 8

Broad D (2004) South Africa Activities and Opportunities. An Unpublished Power Point Presentation to Petro China

Broad DS, Jungslager EHA, McLachlan IR, Roux J (1996) Geology of offshore Mesozoic basins: Contribution to a text book on the geology of Africa published by the Geological Society of South Africa, pp 6-10, 15-19

Brown LF, Benson JM Jr, Brink GJ, Doherty S, Jollands A, Jungslager EHA, Keenan JHG, Muntingh A, van Wyk NJS (1995) Sequence stratigraphy in offshore South African divergent basins: An atlas on exploration for Cretaceous lowstand traps. AAPG, Soekor (PTY)

Chardac O, Murray D, Carnegie A, Marsden JR (2005) A Proposed Data Acquisition Program for Successful Geomechanics Projects. 14th SPE Middle East Oil and Gas Show and Conference, Bahrain. SPE \# 93182

Davies CPN (1988) Bredasdorp Basin—south flank hydrocarbon expulsion. SOEKOR unpubl. Rept., pp. 17

Davies CPN (1997) Unusual Biomarker maturation ratio changes through the oil window, a consequence of varied thermal history. Org Geochem 27(7/8):537-560
Eaton BA (1975) The Equation for Geopressure Prediction from Well Logs. Society of Petroleum Engineers. SPE 5544

Horsrud P (2001) Estimating mechanical properties of shale from empirical correlations. SPE Drill Complet 16:68-73

Jurina L, Gioda G (1981) Numerical Identification of soil structure interaction pressures. Int J Numer Ana Meth Geomech 5,33-51,1981

Keaney G (2005) Geostress and wellbore stability short course. Knowledge systems

Kirsten HAD (1976) Determination of rock mass elastic modulus by back analysis of deformation measurement. In: Proceedings of the Symposium on Exploration for rock Engineering, Johannesburg, 1976

Larsen M (1995) Overpressure study. SOEKOR unpubl. Tech. Note No. 29 , pp. 12

McAloon W, Webster M, Elliot S (1990) The occurrence of overpressure in the South African continental shelf. Abstracts Geocongress 90, Geol. Soc. S. Afr., 349-352

McMillan IK, Brink GJ, Broad DS, Maier JJ (1997) Late Mesozoic sedimentary basins off the Coast of South Africa: Sedimentary basins of the world, African basins, 3rd ed. edited by R.C. Selley, pp 319-376

Petroleum Agency SA (2005) South African Exploration Opportunities, South African Agency for Promotion of Petroleum Exploration and Exploitation, Cape Town, pp. 27

Plumb R, Edwards S, Pidcock G, Lee D, Stacey B (2000) The Mechanical Earth Model Concept and Its Application to High-Risk Well Construction Projects. IADC/SPE Drilling Conference, New Orleans, Louisiana. IADC/SPE \# 59128

Rocha LAS, Falcão JL, Goncalves CJC, Toledo C, Lobato K, Leal S, Lobato H (2004) Fracture Pressure Gradient in Deepwater, IADC/ SPE Asia Pacific Drilling Technology Conference and Exhibition, Kuala Lumpur, Malaysia, 13-15, SPE Paper 88011

Rowsell DM, De Swardt AMJ (1976) Diagenesis in Cape and Karoo sediments, South Africa, and its bearing of their hydrocarbon potential. Trans Geol Soc S Afr 79(1):81-145

Sakurai S, Takeuchi K (1986) Back analysis of measured displacements of tunnels,Rock. MechRock Eng 16:173-180,1986

Santana L (2010) Manual for using density correction software. Internal manual, PetroSA, CAPE Town South Africa, pp 2-12

Tang H, Luo J, Qiu K, Tan PC (2011) worldwide pore pressure prediction: case studies and methods.SPE-140954-MS. SPE Asia Pacific Oil and Gas Conference and Exhibition, 20-22 September, Jakarta, Indonesia

Turner JR, Grobbler N, Sontudu S (2000) Geological modelling of the Aptian and Albian sequences within Block 9, the Bredasdorp Basin, offshore South Africa. J Afr Sci 31(1):80

Van der Merwe R, Fouché J (1992) Inversion tectonics in the Bredasdorp Basin, offshore South Africa. In: De Wit MJ, Ransome (eds) Inversion tectonics of the Cape Fold Belt, Karoo and Creataceous Basins of Southern Africa. I.G.D., A.A. Balkema, Rotterdam, pp 49-59

Verfaille EJJ (1993) A synopsis of RFT data acquired in wells in the Bredasdorp Basin, including regional plots. SOEKOR unpubl. Rept., SOE-PET-RPT-107

Ward CD, Coghill K, Broussard MD (1995) Pore- and fracture-pressure determinations: effective-stress approach. JPT, pp. 123-24

Winter H de la (1981) Progress report on geopressure interpretation: volumes 1 and 2. SOEKOR unpubl. Rept., pp. 57

Zhao H, Shunde Y (2009) Geomechanical parameters identification by particle swamp optimization and support vector machine. Appl Math Model 33:3997-4012

Zoback MD, Barton CA, Brudy M, Castillo DA, Finkbeiner T, Grollimund BR, Moos DB, Peska B, Ward CD, Wilprut DT (2003) Determination of stress orientation and magnitude in deep wells. Int J Rock Mech Mining Sci 40(2003):1049-1076

Publisher's Note Springer Nature remains neutral with regard to jurisdictional claims in published maps and institutional affiliations. 